\title{
O conflito Israelo-Palestino visto pelo cinema local
}

The Israeli-Palestinian conflict seen by the local cinema

\author{
Monique SOCHACZEWSKI \\ Escola de Ciências Sociais CPDOC/FGV, Rio de Janeiro, RJ, Brasil. \\ Contato: monique.goldfeld@fgv.br
}

\begin{abstract}
Resumo: Há uma efervescente literatura tratando da temática dos conflitos entre Israel e os palestinos, assim como com os países árabes. Durante muito tempo, a filmografia a este respeito se resumia a poucos diretores, como o israelense Amos Gitai. Na última década, porém, uma série de obras audiovisuais feitas por cineastas locais sobre essas questões tem ganhado as telas do mundo e abocanhado inúmeros prêmios. O intuito neste artigo é justamente apresentar e analisar algumas destas obras, começando por breve reflexão sobre a importância de filmes de ficção e documentários para tratar da História do tempo presente do Oriente Médio. A Noiva Síria, Lemon Tree, Laila's Birthday, Paradise Now, 5 Broken Cameras e The Gatekeepers, três obras israelenses e três palestinas, são então as selecionadas para, a partir delas, tratar de representações e interpretações feitas sobre o estágio do conflito entre israelenses e palestinos na última década, bem como suas relações com o Oriente Médio, de maneira geral.
\end{abstract}

Palavras-chave: cinema; Israel; Palestina.

Abstract: There is an effervescent literature dealing with the themes of conflicts between Israel and the Palestinians as well as the Arab countries. For a long time the filmography about this came down to a few directors, like the Israeli Amos Gitai. In the last decade, however, a series of fiction films and documentaries made by local filmmakers on these issues has gained the screens of the world and won numerous awards. The purpose of this article is precisely to present and analyze some of these works, beginning with brief reflection on the importance of audiovisual works to reflect on the history of this time in the Middle East. "The Syrian Bride", "Lemon Tree", "Laila 's Birthday", "Paradise Now", "5 Broken Cameras" and "The Gatekeepers", three Israeli works and three Palestinian works, are then selected to deal with representations and interpretations made about the stage of the conflict between Israelis and Palestinians over the last decade, as well as its relations with the Middle East in general .

Keywords: cinema; Israel; Palestine.

\section{Introdução}

Há uma efervescente historiografia e literatura lidando com a temática dos conflitos entre Israel e os palestinos, assim como entre Israel e os países árabes. ${ }^{1}$ Durante muito tempo, a 
filmografia a este respeito que chegava além das telas do Oriente Médio se resumia a poucos diretores, como o israelense Amós Gitai, responsável por filmes como Kippur (2000), e Kedma (2001). Na última década, porém, uma série de filmes de ficção e documentários sobre essas questões, feitos por cineastas locais, judeus e árabes, tem ganhado as telas do mundo e abocanhado inúmeros prêmios de primeira grandeza.

A quase totalidade destas produções cinematográficas chega ao público brasileiro mediante mostras e festivais internacionais de cinema e da TV a cabo, além da internet. E já existem análises acadêmicas no Brasil sobre algumas produções médio-orientais, sobretudo no âmbito dos estudos da Comunicação Social. ${ }^{2}$ Pretendo aqui, porém, propor uma abordagem histórica buscando apresentar a trajetória da filmografia sobre e da própria região a respeito do conflito israelopalestino, para então centrar-me em três obras israelenses - A Noiva Síria, Lemon Tree e The Gatekeepers - e três palestinas - Paradise Now, Laila's Birthday e 5 Broken Cameras . ${ }^{3}$ O objetivo é mais fazer um mapeamento de conteúdos destas produções recentes do que análises exaustivas e aprofundadas, e serão ressaltados alguns temas recentes comuns e também omissões importantes.

É certo que há amplo, longevo e aprofundado debate metodológico sobre a lida entre História e cinema. Por um lado, não resta dúvida de que o cinema é hoje tido como um objeto legítimo de pesquisa do historiador, configurando-se como um documento histórico, e que as análises do filme devem levar em conta, além de seu conteúdo, suas circunstâncias de produção, exibição e recepção. Por outro lado, existem propostas de abordagens diferentes sobre a lida com este. O historiador francês Marc Ferro (2010) insiste na particularidade do trabalho com esse tipo de fonte, sob a visão de que o filme é tanto um produto como um agente da História, e na possibilidade de se buscar o que há de "não-visível" no filme. Segundo seu método, há de se levar em conta na análise o que é filme - planos, temas - com o que não é filme - autor, produção, público, crítica, regime político. Ferro nos auxilia aqui, portanto, na apresentação das obras cinematográficas e na busca de melhor compreensão de uma "contranarrativa" local que busca dar conta do conflito israelo-palestino.

O cineasta, teórico e crítico de cinema também francês Jean-Louis Comolli, por sua vez, é convocado aqui por sua exortação de ser o cinema a mais política de todas as artes, já que ele força e, às vezes, "constrange, o espectador a se incumbir - imaginariamente - de uma parte da mise-enscène, a se virar nela, e então elaborar sentido”. (COMOLLI, 2008, p. 106). Comolli nos ajuda aqui a ter o cinema como arte política em foco, mesmo quando as declarações dos envolvidos com esta no caso, os cineastas - sejam o contrário. Isso se dá, especialmente, quando contrastamos suas obras com a forma como tradicionalmente as mídias, sobretudo ocidentais, tratam do conflito israelopalestino. 
Já o historiador espanhol Joan Del Alcázar (2012) nos serve de grande auxílio por sua defesa do papel dos chamados Documentos em Suporte de Vídeo (DSV) como material didático para os profissionais de História. A seu ver, o uso do filme como recurso didático rompe, por um lado, com o que chama de "dinâmica de monólogo dos meios de comunicação de massas - em que a informação se oferece sempre interpretada" e busca despertar a capacidade crítica do estudante e o levar a refletir sobre os acontecimentos observados. Por outro lado, tanto o filme de ficção como o documentário "têm uma força extraordinária na compreensão das complexidades dos fenômenos ou processos históricos”. (ALCÁZAR, 2012, p. 653). Essa defesa, por parte de Alcázar, do cinema para ensinar História, em especial do tempo presente, advém justamente de sua experiência docente na Universidade de Valência, com cursos sobre a América Latina. Nossa ideia de artigo aqui apresentada, por sua vez, nasceu justamente da experiência com cursos sobre a história e atualidade do Oriente Médio, para o público universitário e para o público leigo, em que se faz largo uso de projeção e debate sobre filmes. $^{4}$

E neste caso aqui, acredita-se que uma possível contribuição a ser oferecida é a de, justamente, propor a pensar nestes filmes como instrumentos didáticos para professores de História e áreas correlatas que lidem com a história e temas correntes do Oriente Médio. As produções cinematográficas aqui tratadas não contam originalmente com claro objetivo pedagógico de se prestarem também a campanhas públicas educacionais, mas acabam servindo a este propósito. Podem ser usadas - e até mesmo já o vêm sendo - para dar conhecimento mútuo entre israelenses e palestinos; podem mostrar para o Ocidente, ainda refém de uma cobertura jornalística superficial, as complexidades de ambos os lados; e podem ainda servir de importante instrumento pedagógico para professores de História e afins aqui no Brasil, interessados em apresentar o conflito israelo-palestino para além de engajamentos identitários ou político-partidários e também da cobertura apressada, ou simplesmente traduzida, da mídia local.

Pretende-se então apresentar brevemente a imagem que o Ocidente, sobretudo os Estados Unidos, criou do conflito israelo-palestino em seu cinema e igualmente relatar o desenvolvimento do cinema no Oriente Médio, inserindo-se as produções palestinas e israelenses nesta narrativa. Parte-se então para uma apresentação dos seis filmes escolhidos, com foco no que há de "filme" e de "não filme" em cada um deles, conforme as indicações de Marc Ferro, para então apresentar algumas considerações sobre questões políticas que deles advêm, bem como sua eventual importância como instrumento didático. ${ }^{5}$

\section{1. Árabes, muçulmanos e palestinos no cinema ocidental}


Edward Said, em seu clássico Orientalismo, publicado originalmente em 1978, dedicou-se a demonstrar como o Oriente retratado na literatura europeia dos séculos XVIII ao XX era, em grande medida, idealizado e mitificado, não necessariamente condizente com a realidade. Havia uma agenda política de poder que visava a "dominar, reestruturar e ter autoridade sobre o Oriente". (SAID, 2007, p. 29).

Jack Shaheen aprofundou a questão de Said no âmbito da representação de árabes na mídia norte-americana. Sua pesquisa de fôlego sobre a projeção de imagens dos árabes nos filmes ocidentais durou mais de trinta anos e acabou convertida no livro Reel bad Arabs: how Hollywood vilifies a people, publicado em 2001, e no documentário de mesmo nome, lançado em $2007 .{ }^{6}$ Shaheen, atualmente vinculado ao Hagop Kevorkian Center for Near Eastern Studies, da New York University, assistiu e analisou cerca de mil filmes, com o que constatou a construção de uma imagem negativa dos árabes e muçulmanos, ao longo do tempo, e entendeu ser este o grupo étnico mais vilificado no cinema Made in USA.

Grosso modo, poderíamos dividir a pesquisa de Jack Shaheen em três partes: 1) resquícios de um orientalismo europeu, no entre guerras, mas ainda presente posteriormente; 2) preconceito próprio norte-americano, após a Segunda Guerra Mundial; 3) visão mais realista e empatia crescente, na virada do milênio.

O cinema norte-americano desde seus anos iniciais perpetuava um orientalismo europeu com uma espécie de "Arabland", uma terra árabe indefinida, em que figuravam o deserto como lugar assustador, odaliscas sensuais, tapetes voadores e encantadores de serpentes. Esse foi o caso de Samson against the sheik (1962), Harum Scarum (1965) e mesmo do desenho animado Aladdin (1992). E os árabes eram retratados em sua maioria como bufões, atrasados, incompetentes, perigosos e pervertidos sexuais em filmes como Os caçadores da arca perdida (1981) e Joia do Nilo (1985).

Já após a Segunda Guerra Mundial, a figura dos árabes passou crescentemente a estar mais atrelada com a política nos Estados Unidos, configurando-se como uma ameaça. Isto se deu, sobretudo, em razão de três temas de crescente interesse norte-americano: o conflito israelopalestino, o embargo ao petróleo no contexto da guerra de 1973 e a revolução iraniana de 1979. A partir da década de 1970 cada vez mais o Oriente Médio passava a estar presente na vida cotidiana dos Estados Unidos - na medida em que a suspensão de suprimento de petróleo impactava na locomoção diária - e os estereótipos dos árabes retratados nas telas eram os sheiks que queriam comprar os Estados Unidos ou dominar o mundo. Este foi o caso de Network (1976), Rollover (1981) e Indiana Jones e a Última Cruzada (1989).

De acordo com Shaheen, os muçulmanos, em geral, e os palestinos, em particular, eram demonizados, normalmente retratados como terroristas. Se por um lado há larga produção que 
mostre israelenses como vítimas inocentes, entre os anos 1980 e 1990 há cerca de 30 filmes feitos sobre essa temática, e neles os palestinos basicamente sequestram, torturam, executam e cometem ataques terroristas. É o que se vê em The Delta Force (1986) e True Lies (1994). Jack Shaheen diz não haver um único filme em que se demonstre empatia ou compaixão pelos palestinos, que os humanize ou retrate como vítimas de uma ocupação, sofrendo diariamente casos de abusos e humilhação.

Já por volta da virada do milênio surgiram os primeiros filmes de fato empáticos, em que árabes e muçulmanos em geral aparecem como pessoas comuns, como mulheres que estudam, adolescentes vidrados por tecnologia e pais carinhosos, por exemplo, ou com um largo passado de tolerância em relação aos cristãos e judeus. Para Shaheen, surge finalmente uma humanização crescente e diminuição do preconceito no cinema norte-americano sobre o Oriente Médio. Filmes como Hideous Kinky (1998), A Perfect Murder (1998), Farenheit 911 (2004) e Kingdom of heaven (2005) atestam tal visão. O próprio Shaheen teve um papel nessa mudança, já que atuou como consultor dos filmes Três reis (1991) e Syriana (2005). ${ }^{7}$

\section{Breve história do cinema médio-oriental}

O cinema árabe nasceu quase que em paralelo com o cinema ocidental, tendo o Egito como polo inicial. Este foi o primeiro país árabe a criar uma indústria cinematográfica nacional, e serviu então de modelo para o Líbano, Síria e Iraque. (SHAFIK, 1998, p. 1). As primeiras apresentações cinematográficas ali se deram pela primeira vez em 1896. Já o primeiro cinema regular se estabeleceu em 1906, e 11 anos depois era criada a primeira companhia egípcia, com recursos italianos. Nos anos 1930 o Egito já contava com sete estúdios, e mais de três dezenas de filmes já tinham sido feitos no país.

Durante muito tempo, o cinema egípcio se manteve inconteste no papel proeminente de maior produtor de cinema distribuído largamente pelo mundo árabe e também assistido por expatriados árabes pelo mundo. O cinema palestino recentemente, porém, emergiu como um forte rival no mundo árabe, produziu um número significante de filmes que também vêm sendo distribuídos globalmente, dando-se aos palestinos uma nova voz. (KHATIB, 2006, p. 2; 11).

O conflito israelo-palestino serviu como tema muito presente dos filmes produzidos no mundo árabe após-1948, em especial no Egito e na Síria. No geral, a representação do conflito era um tanto focada no pan-arabismo (com exceção dos filmes palestinos), ao mesmo tempo que mostrava simpatia pelo sofrimento dos palestinos, e assim celebrava-se a resistência árabe a Israel. Estes filmes retrataram o nacionalismo israelense como imperialista, e os israelenses eram apresentados como um grupo homogêneo que se colocava contra o bem-estar do mundo árabe. 
Filmes como Road to Eilat, Trap of Spies, Love in Taba e Girl from Israel retratavam os israelenses de maneira não muito diferente da lista de estereótipos usados para os terroristas árabes por Hollywood, associados ao mal, ao decadente e ao colonizador. (KHATIB, 2006, p. 121-2). A mensagem predominante era a de antinormalização, questão complicada com a assinatura do tratado de paz entre Egito e Israel, em 1979.

Já os filmes palestinos apresentavam tanto a vilania israelense como atos de resistência dos palestinos. Vê-se neles fortes declarações contra a opressão, com uma voz finalmente concedida aos palestinos contra o discurso dominante que foi construído de serem anômalos ou vitimizados. Em seu cinema, os palestinos não se mostram fracos, são testemunhas de uma história cruel, mas também donos de esperança e resiliência. (KHATIB, 2006, p. 126). Os filmes ali feitos nos anos 1980, tendo como marco inicial Return to Haifa (1980), de Kassem Hawak, retratavam "realisticamente" a resistência palestina, mas, na virada dos anos 1990 para o novo milênio, novos filmes foram feitos focados em representações metafóricas, com largo uso do simbolismo e surrealismo para retratar a realidade palestina. Este foi o caso de Tale of Three Jewels (1995), Crônica de um desaparecimento (1996) e Intervenção Divina (2002).

Elia Suleiman é o diretor de Crônica de um desaparecimento e Intervenção Divina. O último filme é uma comédia surreal e uma tragédia moderna sobre a ocupação israelense de territórios palestinos, e fez grande carreira internacional, chegando a ganhar o prêmio do júri do Festival de Cannes. Chegou a ser indicado para competir ao Oscar, mas não pôde seguir nesta competição porque a Academia não reconheceu a Palestina como um país. De certa forma, abriu o caminho internacional mais amplo para produções palestinas.

\section{Três visões israelenses}

Ainda na virada do século XIX para o XX, filmagens foram feitas na Palestina otomana pelos irmãos Lumière, no intuito de mostrar sequências "exóticas" da "Terra Santa", ou pelos primeiros pioneiros judeus a fazerem documentários. Nas décadas de 1920 e 1930, durante o mandato britânico, esboçavam-se experiências cinematográficas que se consolidaram em um cinema nacional após 1948. A produção, porém, nunca foi muito vasta, com cerca de dez filmes anuais até os anos 1990. Em uma fase inicial, o cinema local tratava de uma construção nacional idealizada e "mítica", em que heroicos israelenses se relacionavam com árabes e palestinos desumanizados, em filmes como Amud haEsh (1959) e Giva 24 Eina Ona (1955). Por boa parte deste período, atores judeus de origem oriental (mizrahim) representavam os palestinos e os árabes, em geral, nas produções israelenses. 


\section{Monique Sochaczewski}

Já por volta dos anos 1980 surgiram os primeiros filmes não-maniqueístas, como Hamsin (1982) e Magash haKessef (1983), que apresentavam uma "luta complexa entre adversários reconhecidamente humanos", e pela primeira vez se escalavam atores palestinos para representarem palestinos. (SHOHAT, 2010, p. 3; 257).

Com os crescentes debates sobre identidade multicultural, pós-colonialismo e pós-sionismo durante os anos 1990 surgiram também experiências mais plurais nas práticas culturais israelenses, inclusive no cinema. O israelense retratado já não é necessariamente o "sabra euro-israelense" ou o imigrante sefaradi-mizrahi; as questões não são mais de guerra nacional ou tensões étnicas, e o hebraico não é mais a única língua empregada. O filme Cup Final (1991) de Eran Riklis mostra soldados israelenses e palestinos comungando do desejo de ver um jogo da Copa do Mundo, e em Café Noah (1996) Duki Dror usa a língua árabe em sua produção. Filmes mais matizados como estes tiveram relativo impacto dentro de Israel, mas passaram a circular mais amplamente nas telas mundiais na última década.

\subsection{A Noiva Síria}

A Noiva Síria não trata do conflito israelo-palestinos nos territórios ocupados da Cisjordânia ou de Gaza, mas nas colinas do Golan, território sírio ocupado por Israel em 1967 e anexado ao país em 1981, portanto, na fronteira setentrional com a Síria. Não são palestinos os retratados, mas drusos. O filme retrata o dia do casamento de Muna (Clara Khoury) e seu primo, que é um ator famoso de novelas na Síria e mora em Damasco. A aldeia de Majdal Shams é retratada com sua "peculiaridade" de ser uma aldeia drusa hostil a Israel e leal à Síria, já que no geral os drusos de Israel são cidadãos do país e, inclusive, seus homens servem ao exército. O patriarca da família, Hamed (Makram Khoury), já fora preso pela polícia israelense por sua atuação justamente próSíria. Quatro de seus cinco filhos são retratados com atenção no filme, e com suas histórias se vislumbra um microcosmo de questões pontuais de uma aldeia drusa - como conselheiros idosos que demandam continuidade de tradições, dilemas de uma mulher drusa, bem como a "política maior".

Muna é uma noiva atípica por estar profundamente triste no dia de seu casamento. E tal fato se dá por causa do envolvimento de seu casamento com questões políticas. Uma vez que, para se casar com seu primo e ir morar com ele em Damasco, ela deve abrir mão da "cidadania israelense" (na realidade, sua carteira de identidade mostra uma "cidadania indefinida"), e uma vez que passe para o território da Síria não poderá nunca mais voltar a ver sua família.

Muna tem 25 anos e demonstra bastante apreensão sobre como vai ser sua vida no outro país e com o marido, que não conhece pessoalmente. Sua irmã mais velha, Amal (Hiam Abbas), por sua 
vez, já tem um longo casamento com o também druso Amin e é mãe de duas filhas já adolescentes. Dedicou sua vida a seguir as tradições do clã e, uma vez que as filhas estão crescidas, quer estudar assistência social na Universidade de Haifa, para a qual foi aceita. Seu marido resiste em deixá-la realizar seu sonho por temer ser visto como fraco pela aldeia.

Outro irmão de Muna é Hattem (Eyad Sheety), que foi estudar na Rússia e lá se casou e teve um filho com uma moça do local (Evelyne Kaplum). Seu pai havia então cortado relações por ele ter se casado com uma não-drusa (ele foi banido pelos anciãos do vilarejo por tal feito, e o pai é ameaçado de ter o mesmo fim se aceitar o filho de volta), e no filme vê-se a tensa relação entre os dois, com Hattem querendo se aproximar e o pai se esquivando ao máximo. Marwan (Ashraf Barhom), o filho mais novo, começa no filme voltando de viagem à Itália, onde vive. Parece na realidade ser uma espécie de malandro, que negocia de tudo um pouco e paquera todas as moças ao redor, incluindo-se as funcionárias estrangeiras da Cruz Vermelha que atuam na fronteira. Um outro filho vive no lado sírio e só se comunica com a família por megafone, próximo à divisa.

A "política menor" e a "maior" estão presentes desde o início. O pano de fundo do casamento de Muna é justamente a sucessão presidencial na Síria, no verão de 2000, quando Hafez al-Assad morre e seu filho Bashar assume seu lugar. A aldeia de Majdal Shams faz manifestações de apoio à Síria, e a polícia israelense acompanha de perto. E o casamento em si mostra a realidade da fronteira entre "calma”, mas não oficialmente em paz, entre Israel e Síria. A ONU e a Cruz Vermelha são as instituições que fazem a mediação entre ambos os lados. Jeanne (Julie-Anne Roth), uma funcionária francesa da Cruz Vermelha, tem a incumbência de levar o passe de Muna para o lado sírio, fornecido por um burocrata israelense enviado especialmente de Jerusalém para o posto na fronteira. Novas regras indicavam, porém, que um carimbo de Israel deveria ser afixado no passaporte de Muna, e os soldados sírios não o aceitam porque daria a ideia de que reconheceriam que o Golan era israelense, quando na realidade o consideravam sírio. A funcionária fica entre várias idas e vindas, além de ansiosa com a possibilidade de poder perder seu voo de volta para a Europa, até que Muna se cansa de tudo e atravessa a fronteira sem documentação para se juntar à família do noivo.

Uma vez apresentado o filme A Noiva Síria, vale dar atenção para o que há nele de "não filme". Trata-se de uma produção de 2004 dirigida pelo israelense Eran Riklis, que também assina seu roteiro, junto com a árabe-israelense Suha Arraf. É uma das primeiras coproduções do país, que incluiu parcerias de Israel, França e Alemanha; o filme foi lançado e distribuído pela empresa norteamericana Koch Lorber Films. 
Eran Riklis conta que a ideia do filme nasceu da história real das "noivas sírias", com que se deparou quando fez o documentário "Borders" (1999), sobre personagens não óbvios nas fronteiras israelenses. Escreveu o roteiro em hebraico, e nessa língua foram feitos os ensaios com o elenco, na sua quase totalidade composto de atores árabes-israelenses. Na filmagem final, porém, o árabe foi a língua usada em quase todo o filme. (INTERVIEW, 2002).

Algumas projeções foram feitas para árabes-israelenses, como em Nazaré, mas se por um lado saudou-se a visão que mostra a sociedade israelense de maneira mais complexa e diversa, por outro não houve reação entusiasmada. Isso se deveu em parte por se achar que o filme foi brando em situações que, na realidade, são necessariamente duras, como uma cena em que o policial israelense quer prender o pai de Muna e é demovido justamente pelo filho "russo" com alegações jurídicas, ou por mostrar o lado sírio da família ou os soldados sírios da fronteira de maneira quase caricatural. (COOK, 2005). As poucas projeções para o público de países árabes se deram em um festival de Marrakesh, no Marrocos, e em projeções para intelectuais e mulheres de negócio em Amã, na Jordânia, sem grandes debates, porém. O filme não foi aceito no festival internacional de cinema de Dubai.

Em entrevista conjunta, os roteiristas declararam acreditar que o cinema político havia acabado e que surgiam em seu lugar "filmes humanos que lidam com a política", situando-se desta maneira seu trabalho. (ARRAF; RIKLIS, 2008). Riklis também declarou diversas vezes que entende a linguagem do cinema como universal e faz seus filmes, portanto, para o mundo. E, de fato, a recepção internacional foi muito boa, o filme abocanhou cerca de 15 prêmios no mundo todo, entre os anos de 2004 e 2005, como o Grand Prix no Montréal World Filme Festival, o prêmio de melhor roteiro no Flanders International Film Festival, o prêmio da audiência no Locarno International Film Festiva, e teve Hiam Abbas como indicada ao prêmio de melhor atriz no European Film Award.

O interesse do público israelense, porém, não correspondeu ao internacional, com poucos expectadores nos cinemas e nenhum prêmio no país, apesar de várias indicações. Segundo reflexão por parte dos roteiristas, tal fato talvez tenha se dado por haver ainda uma tendência do establishment cinematográfico israelense em privilegiar filmes centrados em temática judaica ou porque os juízes das premiações não reconheceram os protagonistas do filme como parte da sociedade israelense. (MY WET, 2005).

\subsection{Lemon Tree}

A história principal de Lemon Tree é de uma viúva palestina, Salma Zidane (Hiam Abbas), e sua plantação de limões. Logo após assumir o ministério da Defesa, o israelense Ysrael Navon 
(Doron Tavory) e sua esposa, Mira (Rona Lipaz-Michal), se mudam para a casa ao lado da propriedade de Salma, na Linha Verde (entre a Cisjordânia e Israel). Por recomendação do serviço de segurança que teme que terroristas ali se escondam, a plantação é cercada e declarada área militar, sendo oferecida uma recompensa em dinheiro para Salma.

Salma perdera a mãe aos cinco anos e fora criada pelo pai e pelo empregado da plantação, tendo-se ligado bastante à terra e ao trabalho com os limoeiros. Quando ficou viúva, retirou da plantação de limões o sustento dos três filhos. Quando recebe a primeira intimação do soldado israelense indicando que não poderia mais ter acesso a seu pomar, vai buscar ajuda de Abu Camal (Makram Khoury), um conhecido que domina o hebraico, para traduzir o documento. Ele lhe avisa que ela não deve cogitar aceitar a recompensa em dinheiro oferecida pelo exército. Ela procura a administração civil israelense e é avisada por um soldado que fala árabe que seu caso é pequeno em relação aos dos demais palestinos e que uma recompensa já era oferecida, já havia, portanto, uma solução.

Salma não desiste e decide então agir por meio da justiça israelense; para isso, busca a ajuda de um advogado. Trata-se de Zyad Davut (Ali Suliman), um advogado palestino que vivera na Rússia por muitos anos (e lá tinha uma filha) e que acaba de fato aceitando seu caso. Eles perdem sumariamente na primeira instância, e a corte rejeita apelo. Salma chora, mas decide continuar a luta na Suprema Corte.

A mulher de meia-idade palestina se angustia com a cerca colocada em torno de seu pomar, sem que possa cuidar das árvores. Os frutos começam a apodrecer, e as árvores ficam doentes sem que se possa fazer nada. De vez em quando, ela pula a cerca e tenta molhar as plantas ou colher alguns limões. O soldado encarregado da torre de vigia próxima tenta alertá-la para não fazê-lo, mas é de fato o agente de segurança que lhe fala rispidamente para que se afaste dos limoeiros.

Salma e Zyad tentam ajuda junto à Autoridade Nacional Palestina (ANP), mas sem sucesso. Ganham um pouco de fôlego quando uma jornalista israelense publica uma matéria de grande circulação com mais informações sobre Salma e com falas favoráveis a ela por parte da esposa do ministro da Defesa, Mira. Diversos grupos de apoio internacionais surgem e visitam Salma. Da mesma forma, quando em visita aos Estados Unidos, o ministro é questionado sobre o caso, assim como em programa de TV israelense. O caso ganha grande repercussão local e internacional.

A Suprema Corte decide, por fim, pela retirada parcial dos limoeiros, e esse foi o fim oficial da luta de Salma. Uma derrota com alguns ganhos. Todo o caso, porém, impactou fortemente no casamento de Ysrael e Mira. Essa passa a se sensibilizar com a situação de Salma e a questionar sua relação com o marido. No final do filme, ela se muda da casa dando a entender que se separou, um muro é erguido entre o pomar de Salma e a casa do ministro (com parte das árvores cortadas). 
Salma queima as roupas do falecido marido, dando a entender viver nova fase, e recebe do funcionário um recorte de jornal que mostra o noivado de Zyad.

Lemon Tree é uma produção de 2008, também dirigida por Eran Riklis, que igualmente assina seu roteiro, junto com Suha Arraf. A mesma equipe de produção de A Noiva Síria foi mantida e acrescida basicamente de israelenses. Foi lançado pela IFC Films.

O filme também foi baseado em uma história real, divulgada em jornais israelenses, mas é ficcional. Segundo os roteiristas, porém, a ideia era tratar do que acontece o tempo todo:

se não são casas, são oliveiras. É assim que o sistema funciona - seja se as pessoas vão à Corte ou não. Este é um filme sobre o conflito entre segurança e pessoas. É uma história universal que se aplica a qualquer lugar. (ARRAF; RIKLIS, 2008).

O própiro diretor citou várias vezes sua visão de Salma como uma espécie de "Erin Brokovitch do Oriente Médio".

O sucesso internacional foi imenso, Lemon Tree ganhou os seguintes prêmios internacionais nos anos de 2008 e 2009: melhor atriz para Hiam Abbas no Awards of the Israeli Film Academy, melhor atriz para Hiam Abbas e melhor roteiro para Eran Riklis e Suha Arraf no Asia Pacific Screen Awards, prêmio Panorama audience para Eran Riklis no Berlin International Film Festival, melhores atrizes para Hiam Abbas e Rona Lipaz-Michael no Cinefan - Festival of Asian and Arab Cinema, e prêmio Silver Apricot de melhor filme no Yerevan International Film Festival.

O público israelense, porém, simplesmente não compareceu aos cinemas. Segundo o próprio Riklis, "foi um desastre" e "pessoalmente uma pena". O diretor acredita que mesmo com uma campanha publicitária que buscava apresentar a obra mais como a história de duas mulheres através da fronteira, havia a desconfiança de que se apresentasse uma heroína palestina. E explica sua relação talvez mais fácil com o tema, diferentemente do que acontece com a maioria dos israelenses, pelo fato de ter morado muitos anos fora de Israel, em países como Estados Unidos, Canadá e Brasil, além de ter estudado cinema na Inglaterra. Seu intuito maior de "ir além das manchetes de jornais" e de mais uma vez fazer um filme não-político, mas sobre "pessoas presas em situações políticas”, não funcionou para seus concidadãos. (JOHNSTONE, 2008).

\subsection{The Gatekeepers}


O documentário The Gatekeepers conta com o depoimento de seis ex-dirigentes da agência de inteligência interna de Israel, o Shin Bet (iniciais em hebraico para Sherut Bitchoni, que significa Serviço de Segurança). Estes relatam a história da atuação do serviço nos territórios ocupados desde 1967, quando foram conquistados por Israel. O Shin Bet é um serviço secreto em que o público só conhece as identidades de seus chefes e estes, historicamente, se expuseram muito pouco na mídia.

Avraham Shalom (1980-1986), Yaacov Peri (1988-1994), Carmi Gillon (1994-1996), Ami Ayalon (1996-2000), Avi Dichter (2000-2005) e Yuval Diskin (2005-2011) falam ao longo de 1 hora e 40 minutos de forma aparentemente sincera sobre sua visão do serviço em si, das conjunturas políticas, da relação com os políticos e com a imprensa, e sobre como veem a situação política atual do Estado de Israel.

O documentário é dividido em "capítulos", anunciados por frases tiradas dos depoimentos que os seguem. Assim, o primeiro é "sem estratégia, somente tática", que trata de um retrospecto da ocupação dos territórios palestinos por parte de Israel após a guerra dos Seis Dias. Surgem ali as memórias do começo da ocupação, em que alguns já serviam ao exército e outros ainda eram crianças, mas que retratam a relação um tanto quanto instintiva por parte dos soldados com os palestinos, "sem indicações de cima como agir". Inicialmente eram palestinos em campos de refugiados, porém, aos poucos surgem os primeiros casos de "terror". Os casos eram poucos, e conseguia-se então engajar habitantes de vilarejos para que apontassem os "terroristas". Já se esboçavam as "necessidades" de fazê-los falar a partir de prisões, investigações e interrogatórios, e já se começava a usar a figura dos colaboradores, pessoas convencidas a "trair seu ambiente, família e amigos". O Estado conseguiu resolver em grande parte a questão do terror, mas não a da conquista, da ocupação.

"Esqueça a moralidade" é o título da segunda parte, e o corte cronológico inicial usado é o do começo dos anos 1980, com a guerra do Líbano, quando o chefe era Avraham Shalom (19801986). Um caso é lembrado então para mostrar o poder que o Shin Bet tinha alcançado dentro do aparato israelense. Nesta época, um ônibus da linha 300, da região de Jerusalém, tinha sido sequestrado por quatro terroristas palestinos. Dois resistiram e foram mortos em combate, mas dois se entregaram desarmados e foram assim fotografados pela imprensa. Acabaram sendo mortos por agentes do Shin Bet, e a questão levantada é o sentimento então de quase onipotência do serviço de inteligência. Avraham Shalom reconhece que autorizou mortes e diz: “com terroristas não há moral. Ache moral em um terrorista primeiro".

O terceiro "capítulo" chama-se "O terrorista de um homem é o guerreiro de liberdade de outro" e já se trata então da primeira Intifada, iniciada em 1987, totalmente inesperada pelo Shin Bet. Reconhecem falha em não ter previsto a revolta, mas se desculpam dizendo que quase todas as inteligências do mundo falharam em previr revoluções. Alguns reconhecem que logo após 1967 
deveria ter sido feito algum acordo com os palestinos. A coisa foi se complicando, e Israel tinha então a maior lista de procurados de todas as inteligências do mundo. Os ex-chefes começam a tratar com mais detalhes de suas relações com os políticos, ressaltando as diferenças entre Itzhak Shamir e Itzhak Rabin em relação aos árabes: o primeiro não acreditava de jeito nenhum em um acordo com eles, o segundo, sim. Relatam que quando dos acordos de Oslo tiveram que se sentar com pessoas que por vezes tinham sido presas por eles próprios e que estes estavam dispostos a negociar. Justamente quando a OLP assumia o governo, o Hamas começava a onda de atentados terroristas suicidas em ônibus por Israel. O Shin Bet sentiu fracasso por casos que não evitou e ao mesmo tempo se via cerceado em relação aos métodos de interrogatório e afins para obter informações que evitassem novos casos. Eles relatam, sobretudo, a dificuldade de então lidar com islamistas, que não tinham nada a perder.

O quarto tópico ganhou o título de "Nossa própria carne e sangue" e volta a meados dos anos 1970 para tratar da construção das primeiras colônias em territórios ocupados por judeus religiosos. A inação por parte dos governos israelenses fez com que os colonos se impusessem, certos da impunidade. Em 1980, um atentado palestino contra colonos foi retaliado com diversos atentados contra prefeitos palestinos, e o Shin Bet descobriu tratar-se de uma milícia judaica perigosa. Planejaram grande ataque contra ônibus palestinos, evitado pelo serviço de inteligência, e tinham ainda o objetivo de explodir o Domo da Rocha em Jerusalém, lugar sagrado para os muçulmanos. Se este tivesse de fato acontecido, teria levado a uma guerra total com todos os países muçulmanos, não só árabes. Itzhak Shamir elogiou a investigação, responsáveis foram presos e julgados, mas logo depois soltos. Esse caso acordou o Shin Bet para que passasse a acompanhar também os "radicais internos". Nunca, porém, tiveram Ygal Amir em sua lista de investigados, e foi justamente ele que emperrou todo o processo de paz ao assassinar o primeiro-ministro Itzhak Rabin. No início de 1995 sentiam que crescia incitamento contra Rabin e pediam para que ele se protegesse, mas ele não o fez. $\mathrm{O}$ assassinato mudou definitivamente a política israelense, deixando clara a polarização, o ódio, que atualmente só piora e pelo que outro assassinato político não está descartado.

"Vitória é te ver sofrer" é a fala selecionada para o quinto módulo. Começa justamente tratando do colapso, do sentimento total de fracasso por parte do Shin Bet com o assassinato de Rabin. O serviço de inteligência mudou totalmente, não mais era baseado em pessoas no "campo", mas em gente atrás de monitores de computadores. Se houve um ganho, este foi na atividade comum com os palestinos na coordenação da inteligência, pois havia interesse comum contra o Hamas. Já não havia, porém, mais clima, confiança mútua ou mesmo desejo de ambas as partes em ter paz após a morte de Rabin. Uma nova Intifada parecia questão de tempo, e de fato ela logo veio com extrema violência de ambos os lados. Em uma conversa com um psiquiatra palestino em 
Londres, Ami Ayalon (1996-2000) ouviu deste que finalmente eles estavam ganhando a guerra, já que sua visão de vitória era ver os israelenses sofrendo, e após 50 anos acontecia uma espécie de equilíbrio de sofrimentos.

Já o sexto capítulo foi chamado de "efeito colateral"; começa tratando da engenhosidade por serviço para assassinar um líder do Hamas responsável por diversos atentados: Yahya Aywaash. Ele acabou morto ao usar o celular, e para alguns o assassinato em tempo relativamente calmo foi erro, por acender o fogo. Logo depois, o assassinato de um líder do Hamas em local que achavam que se encontrava só com a esposa, mas que na realidade estava cheio de civis que morreram também, gerou mais furor. E em 2003, em ocasião em que toda a cúpula do Hamas poderia ter sido morta, acabou não sendo, justamente por cuidado em face da força desproporcional anterior. Ex-chefes discutem a efetividade de matar chefes de organizações, bem como os preços de "overkilling”, e um deles usou mesmo o termo "banalidade do mal" ao tratar destas ações.

"O velho homem ao fim do corredor" foi o título usado para o sétimo e último bloco do documentário. Vê-se aí uma reflexão mais clara sobre o papel dos políticos e seus fracassos, e se chega à conclusão de que a conversa com os palestinos e com os demais inimigos é o caminho. Não veem alternativa a isto. Dror Moreh cita a fala do intelectual Yeshayahu Leibowitz em 1968, um ano após a conquista dos territórios, em que dizia que a ocupação levaria a uma inexorável corrupção moral, corroendo-se a democracia israelense. Yuval Diskin (2005-2011) concorda e Carmi Gillon (1994-1996) diz: "Nós fazemos a vida de milhões de pessoas miseráveis, prolongamos o sofrimento humano". Avraham Shalom, que viveu na Áustria nazista quando criança, usa mesmo a analogia do exército nazista como ocupante, como se os israelenses se parecessem com este. Israelenses passaram a ser cruéis, usando discurso de guerra ao terror. Israel ganha diferentes batalhas, mas perde a guerra.

O documentário The Gatekeepers, de 2012, foi dirigido e produzido pelo israelense Dror Moreh. A produção também coube a Estelle Fialon, da Films du Poisson, e à Cinpehil, e seu orçamento total foi de US\$1.500.000. A coprodução reuniu uma ampla gama de produtores estrangeiros, em especial franceses.

A ideia original teria surgido quando Moreh fazia outro documentário, sobre Ariel Sharon, e soube que foram chefes do Shin Bet que o convenceram a sair de Gaza, em 2005. E Sob a névoa da guerra, documentário de Errol Morris com as lições aprendidas com a guerra do Vietnã pelo exsecretário de defesa dos Estados Unidos, Robert McNamara, inegavelmente lhe serviu de inspiração. 
Em entrevista concedida à revista The Economist, Moreh declarou que seu objetivo com o documentário era o de "mudar o ponto de vista dos jovens israelenses. Contar a eles uma história do conflito israelo-palestino que ainda não lhes foi contada anteriormente”. (POWER, 2013). Já para Al-Monitor, disse que quis "colocar um espelho em frente à sociedade israelense, forçando-a a confrontar a situação em que vivemos”. (ZONSZEIN, 2012). A recepção por parte da imprensa israelense foi ótima, mas já pelo público israelense foi apática. (RUDOREN, 2013). Diplomatas israelenses ao redor do mundo ficaram em especial ansiosos por entender se o filme era bom ou ruim para o país, mas acabaram optando por usar o filme justamente como prova de como Israel é de fato uma democracia, que permite que obras controversas como estas sejam feitas.

O documentário, porém, também fez boa campanha internacional e prêmios de melhor documentário de 2013 da Asian Pacific Screen Awards, da Israeli Fim Academy e da Los Angeles Film Critics Association Awards. Recebeu ainda menção especial por Reports and Social Issues no Biarritz International Festival of Audiovisual Programming, o prêmio de "most valuable documentary of the year" do Cinema for Peace, e foi indicado ao Oscar de melhor documentário.

\section{Três obras palestinas}

Na virada dos anos 1960 para os 1970 - pouco depois do início da ocupação de Gaza e da Cisjordânia pelos israelenses após a Guerra dos Seis Dias - foram realizados os primeiros documentários em campos de refugiados, patrocinados por organizações palestinas. Trata-se da primeira representação da história traumática palestina. Passar-se-ia então a uma fase de produções cinematográficas locais afinadas com o desejo de cristalizar uma "unidade nacional e homogênea e criar símbolos coletivos que se sobrepusessem à realidade, heterogeneidade e diversidade da sociedade palestina”. (GERTZ; KHLEIFI, 2008, p. 4). Os filmes de Michel Kleifi nos anos 1980 tiveram um importante papel em desconstruir esta imagem de unidade e homogeneidade, bem como a evocação de um passado idílico que ainda grassava, trazendo diferentes camadas da realidade palestina.

Surgia então uma geração de cineastas palestinos, ainda na ativa, que levaria adiante estas questões: alguns nascidos e criados nos territórios ocupados, e outros donos de cidadania israelense e cosmopolitas. Durante a segunda intifada, frente à dureza da vida cotidiana, tiveram dificuldades de manter esse cinema mais crítico, com certo retorno à narrativa unificadora. Elia Suleiman, como já dito, destacou-se ao criar um novo tipo de cinema "com novos meios de se relacionar com o passado bem como com a dureza do presente". Seu Crônica de um desaparecimento (1996) não tem passado para retornar nem terra sonhada em que alguém possa chegar e foi parcialmente financiado pelo Israeli Fund for Quality Films. (SHOHAT, 2010, p. 275). É um bom exemplo de uma fase 
mais complexa do cinema "palestino", em que as fronteiras internas e externas ficam mais ambivalentes; ao mesmo tempo que se preocupava com sua autorrepresentação, contava com auxílios de instituições israelenses para levar adiante seus projetos.

\subsection{Paradise Now}

Paradise Now, filme de 2005, conta a história de dois amigos de infância, Khaled (Ali Suliman) e Said (Kais Nashef), que vivem no campo de refugiados de Nablus, na Cisjordânia, e são recrutados para um atentado suicida em Tel-Aviv. O motivo do atentado é vingar a morte de palestinos assassinados em bombardeio israelense.

Ambos trabalhavam em um ferro-velho e eram de origem bastante humilde. Said, porém, carregava o estigma de ser filho de um colaborador (palestino acusado de passar informações para Israel), executado pelos próprios palestinos quando Said tinha 10 anos de idade. São abordados por um certo Jamal (Amer Hlehel), militante de um grupo palestino de resistência que não é identificado, que os dá uma noite para se despedir das famílias. No dia seguinte seguem os rituais dos mártires: tiram fotos que serão usadas em pôsteres, gravam vídeos de despedida, têm os cabelos cortados e corpos lavados, fazem refeição farta, colocam os cinturões com as bombas junto aos corpos e vestem-se de maneira mais parecida com que os colonos israelenses fazem. São instruídos a manter intervalo de 15 minutos entre um e outro para dar maior impacto aos ataques e são informados de que dois anjos os buscarão após os atentados para então ascenderem ao Paraíso.

O plano original era atravessar a Linha Verde, a "fronteira" entre os territórios ocupados e Israel, em área pouco guardada, para serem recebidos do outro lado por um árabe israelense que os ajudaria a perpetrar os atentados em troca de pagamento. Uma patrulha israelense aparece, porém, e os amigos se perdem um do outro. Khaled consegue voltar para o grupo, mas como Said não retorna; o esconderijo é desmontado por temor do grupo de retaliação israelense. Said chega a entrar mais para o território israelense e se aproxima de um ponto de ônibus repleto de colonos judeus religiosos. Um ônibus para e há a chance de perpetrar o ataque suicida, mas uma criança o faz aparentemente desistir.

Volta então para Nablus, e Khaled, depois de alguma dificuldade, o acaba encontrando e devolvendo ao grupo palestino. Na conversa com o líder do grupo, porém, e refletindo sobre sua vida e dos palestinos de uma maneira geral, Said decide que quer ter nova chance de perpetrar o ataque. Reflete sobre o sentimento de humilhação, inferioridade e fraqueza dos palestinos, que vivem sob a ocupação israelense, e entende que a figura do colaborador - como seu pai - é ainda uma forma israelense de explorar essa decadência. 
Se inicialmente Khaled era o amigo resoluto a ir adiante, que grava filme de despedida com convicção e fala dessa certeza quando estão prestes a atravessar a "fronteira", e Said tem dúvidas e titubeia, ao final é Said que ganha convicção de que esse é o único caminho que resta para si e para a resistência à ocupação. Na busca por Said em Nablus, Khaled se encontra com Suha (Lubna Azabal), moça palestina filha de um "mártir" chamado Abu Azzam. Suha milita em grupo de ativistas por direitos humanos e entende que a melhor forma de lutar contra a ocupação israelense que inegavelmente é superior militarmente e ganha simpatia internacional com imagem dos palestinos como terroristas - é por meio de uma "guerra moral". Aparentemente, instala-se a dúvida em Khaled, e este de fato não vai mais adiante com a ideia do ataque suicida.

Na cena final, Said está em um ônibus israelense, no coração de Tel-Aviv, rodeado de soldados. Seus olhos são focados. Tudo fica branco ao final, dando a entender que ele, sim, praticou $\mathrm{o}$ ataque terrorista suicida.

$* * *$

Paradise Now foi dirigido pelo palestino Hany Abu-Assad (um árabe-israelense de Nazaré que se apresenta como palestino e vive há décadas na Holanda) e contou com recursos da Holanda, França e Alemanha. A distribuição nos Estados Unidos foi feita pela Warner Brothers.

O roteiro começou a ser escrito em 1999, mas o filme só foi feito em 2004. Trata-se do primeiro filme a ter terroristas suicidas como tema, e familiares e amigos de perpetradores de atentados suicidas foram entrevistados, assim como foram acessados documentos israelenses como relatórios e transcrições de interrogatórios de suicidas presos. (RIDING, 2005).

O filme foi feito em Nablus, no calor da segunda Intifada, literalmente, já que era verão de 2004, mas algumas cenas tiveram que ser gravadas em Nazaré por razões de segurança. Não houve impedimento formal para filmar, mas as dificuldades da ocupação, da intifada e das lutas internas dos palestinos se manifestaram na forma de ataques aéreos muito próximos ao set e mesmo do sequestro de um membro da equipe. Houve uma negociação diária com grupos diferentes de militantes palestinos, bem como com o exército israelense, para poder se realizar o filme.

O elenco é basicamente composto por atores palestinos que vivem em Israel ou na Europa, mas Lubna Azabal é belga. Os territórios palestinos contam com poucos locais de projeção, mas mesmo assim Abu-Assad diz que foi importante para os palestinos assistirem ao filme e se reconhecerem nele. (INTERVIEW, 2005).

Segundo o diretor, seu filme não é uma declaração política, mas um ponto de vista artístico de questões políticas. Paradise Now recebeu resenhas elogiosas nos Estados Unidos, mas recebeu também vários boicotes no país por ser considerado elogioso ao terrorismo. Por vezes, foi também 
criticado de ser sutil quanto à ocupação israelense e não mostrar cena alguma de violência contra palestinos. $^{8}$

Com todas as polêmicas, Paradise Now recebeu o Globo de Ouro por melhor filme estrangeiro e foi indicado ao Oscar na mesma categoria. Parte da imprensa e grande parte do público israelense, porém, ficaram ultrajados com o filme, que consideraram que humaniza assassinos ou mostra simpatia por perpetradores de atrocidades. Apesar de realizado em territórios palestinos, Paradise Now quase não chegou ao público local.

\subsection{Laila's Birthday}

Laila's birthday versa sobre um dia da vida de Jalal Yacoub (Mohammad Bakri), o dia do aniversário de sete anos de sua filha Laila (Nour Zoubi). Yacoub é advogado de formação, já tinha sido juiz em um "país árabe amigo" e teria sido instado a voltar para a Palestina a convite do próprio Yasser Arafat. Uma vez de volta, porém, não conseguiu de fato ser empossado como juiz e acaba atuando como motorista de táxi (de um carro que pertence ao cunhado) para pagar suas contas.

Como motorista, Yacoub - ou Abu Laila, como é comumente tratado - conta com uma série de restrições: não leva passageiros a checkpoints, não leva passageiros armados, não permite que fumem no seu táxi e exige que aqueles que se sentam à frente usem cinto de segurança. Tenta fazer o que considera certo e ideal em uma cidade cheia de ineficiência e corrupção.

Seu carro quebra, e ele o leva para a oficina de um conhecido. Este considera meia hora para o conserto e diz a Abu Laila que vá a um café próximo enquanto espera, mas pede que lhe compre um pacote de velas. Nesse meio tempo, um míssil israelense atinge um carro, e o dono da oficina usa o táxi de Abu Laila para levar um ferido ao hospital. Abu Laila se inteira de qual hospital se trata e pede carona a outro taxista para chegar lá. Ao chegar, fica sabendo que o homem havia falecido, e lhe é pedido que leve sua viúva a casa. Esta carregava um pacote que deixa no carro.

Ele decide comprar o bolo de aniversário da filha na confeitaria e, enquanto esperava seu táxi, sem que lhe fosse pedido o carro foi enfeitado para um comboio de casamento. Fitas e flores se espalharam pelo capô. Estressado, segue para o posto de gasolina de um conhecido. Ao ver ali um carro da polícia palestina, pega o microfone e começa a dar ordens aos transeuntes e discursar sobre a situação política e social dos palestinos.

Ao final do dia, com todas as situações insólitas, Abu Laila volta para casa para festejar o aniversário da filha. Vê que o pacote esquecido pela viúva era um bolo. Acabou ficando com a vela pedida pelo dono da oficina. Das flores e fitas que enfeitavam seu carro, fez um buquê para a 
esposa. Chega em casa, então, com bolo e presente. Ao ser perguntado pela esposa como foi o dia, responde simplesmente: "como sempre".

Laila's birthday é um filme de 2008 dirigido e roteirizado por Rashid Masharawi. Trata-se do quinto filme do cineasta palestino de Gaza - oriundo de uma família de refugiados de Jaffa, mas que vive e trabalha em Ramallah, na Cisjordânia, onde fundou a Cinema Production and Distribution Center, em 1996, com o objetivo de promover produções locais. O filme é apresentado como originalmente da Palestina, Tunísia e Holanda e ganhou os prêmios Best Asian Feature Film, na Singapura, e International Filme Festival, em 2009.

Abu Laila é interpretado por Mohammed Bakri, ator árabe-israelense com sólida carreira, tanto no teatro e cinema israelenses quanto nos árabes-palestinos. E seu cinema é considerado de certa semelhança com o de Elia Suleiman por ser uma espécie de crônica da ocupação. Trata de um dia ficcional na vida de um palestino comum em uma cidade - no caso, Ramallah, a capital de fato da Autoridade Nacional Palestina - cercada por checkpoints no solo e helicópteros no céu.

Rashid Masharawi sempre foi empenhado em apoiar o cinema palestino, faz mostras itinerantes em campos de refugiados e organiza um festival anual de cinema infantil. Sabe-se pouco, porém, sobre a repercussão interna deste filme.

\subsection{Broken câmeras}

O intuito de Emad Burnat ao comprar sua primeira filmadora era registrar os primeiros momentos da vida de seu quarto filho, Gibril. Ao longo dos cinco anos seguintes, ele filmaria não somente o crescimento de Gibril como a resistência da aldeia de Bilin, na Cisjordânia, à construção de uma cerca em suas terras por parte do governo israelense. Registraria também a completa perda de inocência de seu filho mais novo.

A primeira câmera registrou o nascimento de Gibril e a construção de assentamentos por colonos israelenses bem próximo à aldeia de Bilin. Aos poucos, são apresentados os membros da família de Burnat (sua esposa, Soraya, é palestina, mas foi criada no Brasil) e alguns moradores do vilarejo, como Fil, adulto muito querido pelas crianças, e Adib. Emad Burnat vem de uma família de camponeses que vive da plantação de oliveiras. Organizam-se nesta fase protestos toda sextafeira ao lado da cerca erguida por Israel, com participação de ativistas estrangeiros e também de israelenses. A primeira câmera é atingida, justamente em uma manifestação por um invólucro de gás lacrimogêneo lançado por soldados, e fica inoperante. 
A segunda câmera foi presenteada pelo amigo israelense de Burnat, Ysrael, e logo registra a soltura de um de seus irmãos após um mês preso. Mostra também os progressos de Gibril e suas primeiras palavras, que são: muro, invólucro de gás lacrimogêneo e exército. As manifestações continuam, com ampla e ativa participação de Fil e Adib, e há então registros da guerra de atrito entre os colonos, como o uso de trailers de ambos os lados para já ocupar a terra e queima das árvores caras aos palestinos, por colonos israelenses. As manifestações pacíficas são recebidas a bala pelos soldados israelenses (etíopes e mulheres, entre eles), um ativista israelense é ferido e um outro irmão de Emad é preso. A segunda câmera é destruída por um colono israelense.

A terceira câmera registra o terceiro aniversário de Gibril e a continuação das manifestações semanais. Um outro irmão de Burnat é preso, e cada vez mais o exército israelense se faz presente no vilarejo. Crianças também fazem manifestação, e há mesmo assim reação violenta de Bilin por parte do exército israelense. Burnat é interrogado, preso em prisão comum e depois em prisão domiciliar. O caso acaba sendo encerrado, pois os israelenses "perderam a evidência". Durante uma manifestação, Emad foi alvo de uma bala que acaba se alojando na câmera, com ele salvando-se, assim.

A quarta câmera continua registrando as manifestações de sexta-feira, a partir do inverno de 2008. Burnat explica que o governo israelense temia uma terceira Intifada, e por isso os soldados sofriam pressão para reprimir protestos e não deixar que ganhassem força. A violência cresce com dois meninos, um de 11 e outro de 17 anos, sendo mortos. Emad Burnat fala da "dificuldade da não violência quanto há tanta morte ao redor”. A Suprema Corte israelense decide pela destruição de parte da cerca e há festejos por isso na aldeia, mas um ano depois a cerca ainda está lá. As árvores da aldeia foram queimadas ou arrancadas por bulldozers. Burnat cai em um buraco ao dirigir o trator em suas terras e é salvo por soldados israelenses que o levam para tratamento em Tel-Aviv. É nesta ocasião que a quarta câmera foi quebrada. Ele diz ter consciência de que se tivesse sido levado para hospital palestino não teria sobrevivido, porque não haveria estrutura para tratá-lo.

A quinta câmera mostra a recuperação de Burnat, que não é festejada porque se dá justamente quando Gaza é atacada pelo exército israelense, em 2009. Ele não pode mais fazer trabalho físico algum e está cheio de dívidas pelo tratamento em Israel. Reflete sobre a Autoridade Nacional Palestina que não o ajuda por não ser "verdadeiramente da resistência" e diz que os "rebeldes de verdade" são seus amigos do vilarejo, que não esmorecem com as manifestações de sexta-feira. Filma a Copa de 2010 com os filhos vestidos com o uniforme brasileiro e sempre brincando com Fil. Reflete que a única proteção que pode dar a seu filho menor, Gibril, é permitindo que ele veja tudo: da violência dos soldados nas manifestações ao abate de um carneiro. Numa das manifestações, Fil é morto, e é neste contexto que seu filho lhe pergunta: "Pai, por que é que você não mata os soldados com faca?” É o fim da infância de Gibril e de Daba, irmão de Fil. 
Adib é também detido na frente do filho e passa ao menos um ano preso. A pressão leva ao desmonte da cerca, de fato, mas um muro de concreto é construído não muito longe. Ele diz que, porém, a terra "sempre terá as cicatrizes".

A sexta câmera não foi destruída. Começa mostrando a ida de Emad a Tel-Aviv para retirar os pontos, levando os dois filhos menores para irem à praia pela primeira vez.

5 Broken Cameras é codirigido pelo palestino Emad Burnat e o israelense Guy Davidi. Trata-se de uma coprodução israelense, palestina e francesa, cujo orçamento total foi de US\$250.000. Ganhou mais de 30 prêmios em Israel e pelo mundo afora, incluindo-se o de melhor documentário do Jerusalem Film Festival, o prêmio de direção do Sundance Film Festival (2012), prêmio da audiência do International Documentary Film Festival of Amsterdam (IDFA) e menção do júri e prêmio de melhor documentário do Michael Moore's Documentary Festival in Traverse City. E, diferentemente do que aconteceu com Intervenção Divina, foi aceito como indicado ao Oscar de melhor documentário de 2013, justamente com The Gatekeepers como concorrente. Mas nenhum dos dois foi vencedor.

É válido ressaltar que o caminho seguido pelo filme em prêmios internacionais, bem como sua apresentação na mídia em geral, gerou acalorados debates. Por um lado, Emad Burnat foi largamente criticado em Ramallah "por ter trabalhado com os israelenses”, uma vez que há uma posição consolidada na sociedade palestina de "antinormalização". Guy Davidi, por sua vez, teve muita dificuldade em achar um cinema comercial israelense que projetasse o filme para o público local e chegou a ser chamado de "traidor". (GOLDMAN, 2013).

\section{Considerações finais}

No âmbito da história do cinema, de certo modo concretiza-se a maneira esperançosa e otimista com que Jack Shaheen concluiu sua fala no documentário sobre a forma como os árabes, muçulmanos e palestinos eram retratados na filmografia ocidental. Por um lado, produções hollywoodianas já buscam apresentar os posicionamentos norte-americanos na região de maneira mais crítica, e também os habitantes locais, de maneira menos estereotipada. Por outro lado, essas próprias produções locais vêm ganhando espaço em premiações de primeira grandeza da meca do cinema mundial e nas suas principais praças. Se Jack Shaheen se ressentia que filmes hollywoodianos não humanizavam os palestinos, apresentando-os como seres que têm ligações familiares e dilemas humanos, essa nova filmografia ameniza esta questão, apresenta também 
famílias amorosas - como a união entre irmãos, em A Noiva Síria, e o amor paternal, em Laila's Birthday, o afeto entre amigos, como a amizade de Said e Khaled em Paradise Now, e de Adib e Fil, em 5 Broken Cameras. A questão mais importante de se destacar, porém, é a do protagonismo local - embora ainda em grande parte necessitado do suporte internacional, sobretudo ocidental, para as produções - na concepção, direção, atuação e afins.

Esta filmografia recente sobre o conflito israelo-palestino permite vislumbrar, portanto, uma crescente descolonização do conflito, no sentido de busca por uma narrativa própria e não necessariamente condizente com os interesses de potências ou de elites governantes. Ela permite também verificar uma pertinente interconexão nos filmes em questão, seja com coparticipação de árabes e judeus na direção de produções - como Emad Burnat e Guy Davidi em 5 Broken Cameras - ou na elaboração de roteiros, como se viu nas parcerias de Eran Riklis e Suha Arraf em A Noiva Síria e Lemon Tree. Alguns atores participam de produções de ambos os "lados" também, como é o caso, sobretudo, da atriz Hiam Abbas, presente em três das seis produções (duas israelenses e uma palestina) e amplamente premiada. Já Ali Suliman atua em Lemon Tree e Paradise Now, e Ashraf Barhom em A Noiva Síria e Paradise Now.

E o cinema local de certa forma matiza a cobertura padrão da imprensa internacional e brasileira, focada na violência do conflito e passando a ideia, conforme comentaram alguns alunos em debates em classe, de que este é milenar ou de que os papéis dos israelenses como opressores e dos palestinos como resistentes violentos fossem estanques. Se por um lado há militares israelenses que reagem violentamente contra manifestantes palestinos não violentos, assim como colonos judeus provocadores, em 5 Broken Cameras, o mesmo documentário apresenta o ativista israelense Ysrael que se coloca junto dos palestinos nas manifestações e, inclusive, presenteia Emad com uma câmera; advogados israelenses que se articulam com palestinos para ajudá-los em sua luta na Justiça israelense; ou mesmo o fato de este ter sua vida salva, quando de um acidente de trator; e a medicina oferecida em Tel-Aviv. Por outro lado, a noção de radicalismo islâmico também se mostra matizada. Emad Burnat é uma pessoa claramente religiosa, sua esposa usa hijab para cobrir os cabelos, e sua escolha por resistência na aldeia de Bilin é pela não violência. Já em Paradise Now, a narrativa dos aspirantes a homens-bomba passa longe de fanatismo religioso e mais perto da falta de perspectivas e da humilhação diária por parte da ocupação, em especial na figura do filho de um “colaborador" executado, como Said.

A presença militar impacta na vida diária dos palestinos, e situações kafkianas decorrem delas. A Noiva Síria é todo sobre o absurdo da ocupação e de como, ao se casar com um primo sírio, nunca mais a protagonista poderá voltar para o resto da família em território ocupado por Israel, para além de todas as idas e vindas - literalmente - da burocracia em ambos os lados da fronteira. Lemon Tree trata do absurdo da restrição feita a uma proprietária palestina para acessar sua 
plantação de limões, ao se tornar vizinha do ministro da Defesa israelense. E The Gatekeepers é todo sobre o aparato militar israelense envolvido com a ocupação, mas que fica claro a todos os depoentes o quão ineficiente se mostra, pois “se vencem batalhas, mas não a guerra". Em Paradise Now, ao gravar seu pretenso vídeo de despedida, Khaled começa de repente a falar de um filtro de água que sua mãe deveria comprar, deixando ver a questão do envenenamento de águas por parte de colonos. Em Laila's Birthday, a ocupação se faz presente quando por terra - na forma dos checkpoints de que o protagonista prefere ficar longe - e nos helicópteros que surgem a toda hora, a ponto de levar Abu Laila ao descontrole em determinado momento, quando pega o microfone de uma viatura da polícia e passa a orientar os transeuntes tentando levar ordem ao caos. E, por fim, em 5 Broken Cameras o absurdo está na reação israelense violenta a manifestações não violentas palestinas, sobretudo quando da morte da figura simpática e alegre de Fil.

O que se vê desta filmografia, ainda, é que o conflito é em grande parte masculino, e que as mulheres vivem suas próprias lutas dentro deste. Se em Lemon Tree elas são as personagens principais, em The Gatekeepers elas simplesmente não aparecem, configurando omissão significativa justamente do lado mais "moderno" do conflito, em que as mulheres servem ao exército. Em A Noiva Síria, há por um lado Amal que deseja estudar depois de ter cumprido seus deveres para com a família e o clã, e por outro há Muna que, justamente para cumprir sua tarefa de se casar entre os seus, se afastará para sempre da família. Em Paradise Now, Suha é a mulher palestina forte, opinativa, moderna, que busca por caminho alternativo à violência na resistência à ocupação e que fala alto e apaixonadamente sobre suas convicções. Neste sentido, a filmografia deixa claro existirem várias mulheres palestinas, não sendo possível “essencializá-las”.

A entrada da rede Al Jazeera, do Catar, na briga mundial pela cobertura jornalística representou uma polarização dos discursos sobre o Oriente Médio, tendo redes ocidentais como a CNN na outra ponta a contar a sua "verdade". Isto ficou claro, sobretudo quando da cobertura da invasão norte-americana ao Iraque, em 2003. (RESENDE; PAES, 2011, p. 217). Esta filmografia aqui brevemente tratada, recortada nos últimos dez anos, porém, mostra não somente uma polarização de discursos, mas uma importante matização destes. E aqui vale também refletir em que medida o cinema vem por muitas vezes cumprindo o lugar do "grande jornalismo", talvez por ter mais tempo para se dedicar a seu trabalho, sobretudo no caso dos documentaristas que muitas vezes têm feito, na realidade, reportagens elaboradas. ${ }^{9}$

Cada filme descortina temas de impacto poucos conhecidos mesmo para aqueles já familiarizados com o conflito israelo-palestino. A Noiva Síria mostra o quanto os drusos do Golan também se consideram vítimas da ocupação e se revoltam com esta. Lemon Tree lança olhar sobre a possibilidade de atuação de um palestino junto à Justiça israelense. The Gatekeepers trata de maneira clara da existência de milícias fanáticas judaicas. Paradise Now joga luz sobre a questão de 
"justiçamentos" contra palestinos que colaboram com Israel. Laila's birthday ressalta a ineficiência da gestão palestina na Cisjordânia. E 5 Broken Cameras mostra o impacto da ocupação e da reação violenta de Israel a manifestações não violentas sobre uma criança. E em quase todos eles há alguma presença russa - é o local de origem da esposa não drusa de um dos irmãos de Muna de $A$ Noiva Síria, da mãe da filha do advogado Zyad e também de trabalhadores israelenses a serviço do ministro da Defesa, em Lemon Tree - o que denota um passado de envolvimento soviético com o conflito e origem de milhares de imigrantes para Israel, que escapa a muitos.

Os cineastas das produções aqui tratadas são em geral da mesma geração - na faixa de 50 anos, com exceção de Emad Burnat e Guy Davidi, na faixa dos 30 ainda - e eles próprios têm ligações com a política, já que os israelenses necessariamente serviram ao exército e os palestinos tiveram uma ligação com a ocupação, impactando sua vida diária, ou impactando diretamente nas filmagens. Em geral não consideram sua obra "filmes políticos", mas abordagens artísticas ou humanas, mediante a linguagem do cinema, de temas políticos.

Os filmes em questão se mostram, porém, importantes instrumentos políticos, seja para matizar a narrativa da grande mídia, como já tratado; para auxiliar na "educação" de vários públicos a respeito da complexidade do conflito e da apresentação de sua dimensão humana; ou ainda por reivindicar, de certa forma, uma "descolonização" do conflito, visando a uma narrativa própria e crítica. A noção de "contrapoder" tratada por Manuel Castells (2013, p. 10), de ser esta a capacidade de os atores sociais desafiarem o poder embutido nas instituições da sociedade com o objetivo de reivindicar a representação de seus próprios valores e interesses, parece fazer sentido aqui para entender estas obras. Os filmes em questão são tanto atores como instrumentos de "contrapoder", sobretudo por se oporem à narrativa mestra de seus grupos e àquela consolidada no Ocidente por seu cinema ou pela grande mídia. Se por um lado, contudo, parecem fazer bonito na arena internacional, ganhando prêmios e críticas positivas, internamente sofrem para se fazer conhecidos. São associados às alas esquerdas políticas de ambos os lados, aquelas que buscam a autocrítica ou a coexistência, tachados por muitos como "traidores".

Os próprios possíveis usos didáticos destas obras - já previsto ao menos por uma delas, no caso 5 Broken Cameras, que inclusive levou adiante uma campanha de crowdfunding para arrecadar recursos e chegar às escolas israelenses (BRINGING, [s/d]) - podem ter um impacto político local, gerando questionamento sobre a ocupação e uma atuação política neste sentido. Longe do teatro do conflito, aqui no Brasil servem justamente, conforme indicou Del Alcàzar (2012) sobre as possibilidades didáticas dos filmes, para despertar a capacidade crítica do estudante - ou mesmo do espectador comum - como para apresentar a complexidade específica deste conflito. A apresentação destes filmes no âmbito do curso de inverno "Cinema e Conflito no Oriente Médio" oferecido na Fundação Getúlio Vargas do Rio de Janeiro, em julho de 2014, gerou uma primeira 
reação quase que uníssona nos 20 alunos matriculados: "confesso que eu não sabia nada". Ao final do curso foi interessante verificar uma reação dos alunos no sentido de ressaltar semelhanças com questões presentes no Brasil - como a violência policial em comunidades carentes - e por sentirem que eles configuram uma alternativa às narrativas eurocêntricas ainda prevalecentes por aqui.

A visão mais matizada e humana não esconde, porém, o grande drama da ocupação. E os filmes em questão geram debate público não somente sobre seu conteúdo, mas também sua circulação e impactos políticos. Suha Arraf, corroteirista de Eran Riklis nos filmes aqui apresentados, justamente se encontra desde meados de 2014 no centro de um acalorado debate político a respeito de seu primeiro filme de ficção solo como diretora. Arraf inscreveu seu filme Villa Touma - sobre três irmãs palestinas cristãs que vivem em Ramallah no começo da ocupação israelense - no Festival de Veneza de 2014 como "palestino", mesmo tendo recebido recursos de organizações israelenses. O Conselho do Filme Israelense recomendou o pedido de devolução imediata do dinheiro concedido, e a cineasta reagiu de maneira veemente dizendo que o filme pertence a quem o realiza e não a quem o financia, caso contrário, muitos dos filmes apresentados como israelenses seriam alemães ou de outra nacionalidade europeia em razão do financiamento captado. No debate a seu respeito, Arraf apresentou sua identidade como "uma árabe, uma palestina e uma cidadã do Estado de Israel”. (ARRAF, 2014).

Stuart Hall (1990, p. 222-4), ao comentar a emergência de um cinema caribenho décadas atrás, ressaltou o papel da identidade cultural que se colocava em questão. A posição de enunciação - a posição de quem fala ou escreve ou, aqui no nosso caso, de quem filma - de fato muito importante, embora cambiante e problemática. Há por um lado um reposicionamento importante de quem enuncia a representação do conflito - sendo aqui os próprios envolvidos neste, com uma visão mais matizada da questão. Hall ressalta existirem duas definições de identidade cultural, uma fortemente calcada numa cultura compartilhada de "um povo", e outra que, embora reconheça pontos de similaridade, entende haver pontos cruciais de profunda e significativa diferença que constituem quem "realmente é" ou quem "se tornou". O que se vislumbra das representações feitas por israelenses e por palestinos em suas produções fílmicas da última década vincula-se em grande medida a esta segunda visão. Saem os mitos e encaram-se as rupturas e descontinuidades, numa visada mais cuidadosa do Outro.

\section{Referências}

ARRAF, Suha. I am an Arab, Palestinian and citizen of Israel - I have the right to define my own identity. HAARETZ, 24 ago. 2014. Disponível em: http://www.haaretz.com/opinion/.premium1.612195\#. Acesso em: 30 set. 2014. 
ARRAF, Suha; RIKLIS, Eran. A Cross-Cultural feeling. 2008. Disponível em: http://www.europeanfilmacademy.org/Interview-with-Eran-Riklis-and-Suha-Arraf.183.0.html.

Acesso em 20 abr. 2014.

BRINGING 'Five Broken Cameras' to Israeli youth. [s/d] Disponível em: https://www.indiegogo.com/projects/bringing-five-broken-cameras-to-israeli-youth\#home. Acesso em: 18 abr. 2014.

CASTELLS, Manuel. Redes de indignação e esperança. Movimentos sociais na era da internet. Rio de Janeiro: Zahar, 2013.

COMOLLI, Jean-Louis. Ver e Poder. A inocência perdida: cinema, televisão, ficção, documentário. Belo Horizonte: Editora UFMG, 2008.

COOK, Jonathan. Film review: "The Syrian bride" makes for a difficult marriage. 21 jul. 2005. Disponível em: http://electronicintifada.net/content/film-review-syrian-bride-makes-difficultmarriage/3491. Acesso em 20 abr. 2014.

DEL ALCÁZAR, Joan. Historia desde el cine [y con la literatura] para la educación. Revista Brasileira de Estudos Pedagógicos, v. 93, n. 235, p. 645-666, 2012.

FERRO, M. Cinema e História. São Paulo: Paz e Terra, 2010.

GERTZ, N.; KHLEIFI, G. Palestinian Cinema: Landscape, Trauma and Memory. Edinburgh: Edinburgh University Press, 2008.

GOLDMAN, Lisa. "5 Broken Cameras" director: There is no room for guilt - only taking responsibility. 24 fev. 2013. Disponível em: http://972mag.com/director-of-5-broken-camerasthere-is-no-room-for-guilt-only-taking-responsibility/66642/\#. Acesso em: 13 abr. 2014.

HALL, Stuart. Cultural identity and diaspora. In: RUTHERFORD, Jonathan (ed.) Identity: community, culture, difference. London: Lawrence \& Wishart, 1990.

HROUB, Khaled. Hamas: um guia para iniciantes. Rio de Janeiro: Difel, 2008.

INTERVIEW with Eran Riklis. The Making of "The Syrian Bride". 2002. Disponível em: http://en.qantara.de/content/interview-with-eran-riklis-the-making-of-the-syrian-bride. Acesso em 20 abr. 2014.

INTERVIEW with Hany Abu-Assad. Shooting Paradise Now amid Israeli rockets. 2005. Disponível em: http://en.qantara.de/content/interview-with-hany-abu-assad-shooting-paradise-nowamid-israeli-rockets. Acesso em 20 abr. 2014.

JOHNSTONE, Nick. Why fellow Israelis hated my film. 23 out. 2008. Disponível em: http://www.thejc.com/arts/film/why-fellow-israelis-hated-my-hit-film. Acesso em: 21 abr. 2014.

KAPELIOUK, Amnon. Arafat - O irredutível. São Paulo: Planeta do Brasil, 2004.

KHATIB, L. Filming the modern Middle East. Politics in the cinemas of Hollywood and the Arab World. London/New York: I. B. Tauris, 2006. 
LIMA, Roberto Robalinho. Miragens e estilhaços da guerra: os filmes contemporâneos de ficção sobre a Guerra do Iraque. 2012. Dissertação (Mestrado) - UFF, Niterói, 2012.

MY WET dream is to have a premiere in Damascus. The Guardian, 10 jan. 2005. Disponível em: http://www.theguardian.com/film/2005/jan/10/israelandthepalestinians.world\#. Acesso em: 21 abr. 2014.

MORRIS, Benny. Um estado, dois estados: soluções para o conflito Israel-Palestina. São Paulo: Editora Sefer, 2014.

OREN, Michael. Seis dias de guerra: junho de 1967 e a formação do moderno Oriente Médio. Rio de Janeiro: Bertrand Brasil, 2004.

POWER is in their hands. The Economist, 9 abr. 2013. Disponível em: http://www.economist.com/blogs/prospero/2013/04/qa-dror-moreh. Acesso em: 20 abr. 2014.

REEL Bad Arabs - How Hollywood Vilifies a People. 2006 Documentário. Disponível em: https://www.youtube.com/watch?v=lugFgJn9krI. Acesso em: 14 abr. 2014.

RESENDE, F.; PAES, A. B. The Arab conflicts and the media discourse: A Brazilian perspective. In: Global Media and Communication, 7, p. 215-219, Dec. 2011.

RIDING, Alan. Palestinian Film Looks at Suicide Bombers. The New York Times, 6 set. 2005. Disponível em: http://www.nytimes.com/2005/09/06/movies/06para.html. Acesso em: 13 abr. 2014.

RUDOREN, Jodi. Most Israelis are not listening. The New York Times, 25 jan. 2013. Disponível em: http://www.nytimes.com/2013/01/27/movies/awardsseason/gatekeepers-oscar-nominee-hasmuted-reaction-in-israel.html?pagewanted=all\&_r=0. Acesso em: 20 abr. 2014.

SAID, E. Orientalismo. O Oriente como invenção do Ocidente. São Paulo: Companhia das Letras, 2007.

SHAHEEN, J. Reel bad Arabs. How Hollywood vilifies a people. Northampton: Olive Brach Press, 2009.

SHLAIM, Avi. Muralha de Ferro: Israel e o mundo árabe. Rio de Janeiro: Fissus Editora, 2004.

SHAFIK, V. Arab cinema: History and cultural identity. Cairo: The American University of Cairo, 1998.

SHOHAT, E. Israeli Cinema: East/West and the Politics of Representation. London/New York: I. B. Tauris, 2010.

ZONSZEIN, Mairav. In documentary, former Shin Bet heads question occupation. Al Monitor, 17 dez. 2012. Disponível em: http://www.al-monitor.com/pulse/originals/2012/al-monitor/shin-betheads-occupation.html\#ixzz2GYVA9Dwa. Acesso em: 21 abr. 2014. 
${ }^{1}$ Uma parte desta historiografia já vem sendo, inclusive, traduzida para o português. É o caso, pelo lado israelense, de Benny Morris (2014), de Michael Oren (2004) e de Avi Shlaim (2004). Já quanto ao lado palestino, há a biografia Arafat - O irredutível, de Amnon Kapeliouk, e o livro Hamas: um guia para iniciantes, de Khaled Hroub, entre outros.

${ }^{2}$ Ver RESENDE; PAES, 2011, p. 215-219; LIMA, 2012.

${ }^{3}$ Dois filmes de ficção e um documentário "de cada lado" e fillmes que cobrem três "recortes": A Noiva Síria e Paradise Now são de 2004-2005, Lemon Tree e Laila's birthday são de 2008 e The Gatekeepers e 5 Broken Cameras são de 2012. São, assim, representativos da filmografia israelo-palestina na última década.

${ }^{4}$ Os guias de discussão criados pela ONG Just Vision para seus documentários Encounter Point, Budrus e My Neighbourhood serviram não só para os debates após a projeção destes documentários, como também para inspirar discussões a respeito de muitos dos filmes aqui listados.

${ }^{5}$ Para facilitar a leitura, as citações em línguas estrangeiras foram traduzidas livremente para o português.

${ }^{6}$ As citações aqui feitas foram retiradas do documentário que está disponível online. (REEL, 2006).

${ }^{7}$ Já Lina Khatib (2006, p. 108), mais do que periodizar a representação dos palestinos no cinema norte-americano, ressalta três temas como recorrentes: 1) a construção do conflito como um conflito étnico, em que judeus são, sobretudo, representados como donos de um sentimento, história e origem comuns; 2) o estabelecimento de fronteiras físicas e ideológicas entre israelenses e palestinos, que faz com que cada lado pareça ser um grupo homogêneo, sendo os palestinos em grande parte "orientalizados"; 3) a representação dos Estados Unidos como um padrinho, certamente com ligações mais fortes com Israel, mas que se situa numa posição superior a ambos e busca mediar a paz não só no Oriente Médio como no mundo todo. Khatib vai um pouco além de Shaheen nesse ponto, ao ressaltar o papel do cinema na criação de uma imagem dos norte-americanos como policiais, salvadores e mantenedores da ordem internacional. A autora, porém, usa basicamente os mesmos filmes para fazer seu ponto, que são Delta Force, The Ambassador e The little drummer girl.

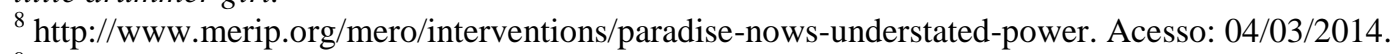

9 "Grande jornalismo" para se contrapor a uma crescente presença de mídia alternativa na região, financiada em parte por crowdfunding e similares, como é o caso de portais como +972, Your Middle East, International Middle East Media Center e mesmo o blog do professor Juan Cole, da Universidade de Michigan. Interessante ainda ressaltar a percepção de grandes redes de notícias em TV, como Al Jazeera e Globonews, da relevância dos documentários no contexto de uma busca por "nova linguagem de jornalismo na TV". A Globonews justamente em 2014 abriu um novo espaço em sua grade de programação para a exibição de documentários feitos dentro e fora do canal. Os temas iniciais destes são bastante internacionalizados, como Venezuela e Namíbia, mas o Oriente Médio parece não constar ainda entre os temas dos primeiros trabalhos.

Monique Sochaczewski é doutora em História, Política e Bens Culturais pelo CPDOC/Fundação Getúlio Vargas e pesquisadora-bolsista da Escola de Ciências Sociais CPDOC/FGV/RJ. 